\title{
Effect of Administering Zeolite on The Physical Performances of Pellet Product Contained Chickens Hatchery Wastes
}

\author{
Sulistiyanto B, Utama SC, Sumarsih S \\ Faculty of Animal and Agriculture Sciences, Diponegoro University \\ Tembalang Campus, Semarang-50275, Central Java, Indonesia \\ bsoel07@gmail.com
}

\begin{abstract}
Wastes of hatchery industries could potentially be used as an alternative feed resource, but had disadvantages in the organoleptic and physical performances. Experiment of pelleting process which was enriched with zeolite was done to improve the physical-organoleptic characters, so it may easy and attractive on handling before being used as an alternative feedstuff to support provision of local feed ingredients. The study was assigned in a completely randomized design with 6 treatments of zeolite additions $(0,1,2,3,4$, and 5\%) and 5 replications. Parameters observed are texture, smell, color and durability of pellet. Data of the parameter such as texture, smell, color were analyzed qualitatively, whereas the parameter of durability was analyzed by analysis of variance. The results found that the texture and color of pellets were not affected by the presence of zeolite, but the odor was significantly eliminated by increasing level of zeolite in the pelleting process. The fishy and foul smell of the hatchery wastes immediately vanished with increasing levels of zeolite. Durability of pellet was not significantly affected by the addition of zeolite. It is concluded that the addition of zeolite in hatchery waste pellet was able to improve the physical performances of hatchery wastes.
\end{abstract}

Key Words: Zeolite, Physical Organoleptic, Hatchery Waste

\section{INTRODUCTION}

Hatchery waste has a good nutrient content, i.e. crude protein $(33.1 \%)$, fat $(29 \%)$, crude fiber (12.1\%), AME (23.9 MJ/kg), calcium (25.62\%) and phosphorus (1.47\%) (Lilburn et al. 1997; Mehdipour et al. 2009). Protein from hatchery waste flour have high biological value, a good balance of amino acids, as well as more competitive prices compared to soybean and fish meal (Lilburn et al. 1997; Shahriar et al. 2008). Our previous experiments noted that the nutritional content of the hatchery waste that consisting of eggs shell, infertile eggs, un-hatched eggs, and the culled DOC have a water content of $\pm 60 \%$, crude protein $\pm 20 \%$ and crude lipid $\pm 9 \%$. Those are supporting factors for the growth of microorganisms, so that the waste will be easily damaged, rotten and smelling when it is not handled well.

Drying and pelletizing are the processing methods that may help to change the physical appearance, while maintaining quality of the processed products of hatchery waste. Heating with high pressure treatments in the pelleting process did not interfere the availability of amino acid and energy and may decrease the feed conversion (Serrano et al. 2013; Cerrate et al. 2009; Cutlip et al. 2008). Pelleting has also been proven increasing the effectiveness of inhibiting growth of the fungi on the feed (Tabib et al. 1984). Physical aspects standard of product quality of pellets are needed, because the pellets could be damaged during distribution, transportation and storage (Aarseth \& Prestløkken 2003; Fasina \& Sokhansanj 1996); so that is necessary to assure that pellet product to have good durability and structures during handling and transporting from mills to animals (Crampton 1985; Behnke 1996). 
Applications of minerals binders in the feed for various purposes have been done, such as the use of kaolin, bentonite and zeolite as feed supplements, calcium lignosulfonate and sepiolite in pelleting broiler feed, sodium bentonite for binding aflatoxin, as well as the zeolite to improve the utility of nutrients (Trckova et al. 2004; Corey et al. 2014; Pasha et al. 2007; Leung et al. 2007; Angulo 1995). Zeolite has been reported safe for poultry feed, improving nutrient utilization as well as animal growth. Zeolite has beneficial effects on feed efficiency ratio, water consumption, nutrient utilization, manure and litter condition (Shariatmadari 2008; Karamanlis et al. 2008). Zeolites have been reported effective in absorbing nitrates and ammonia (Mažeikiene et al. 2008), decreased the number of E. coli (Eng et al. 2003), reduced the effect of aflatoxin on broiler chickens (Miazzo et al. 2000; Afzal \& Zahid 2004), increased the utility of Zn (Watkins \& Southern 1993), suppressed the Salmonella and improved the broiler growth (Al-Nasser et al. 2011; Mallek et al. 2012).

However, there was limited information of zeolite effect on feed processing in particular of hatchery wastes. Therefore, this study specifically examined the ability of zeolite on improving the physical-organoleptic quality of pellet of hatchery wastes that viewed from the texture, smell, color, durability of pellets.

\section{MATERIAL AND METHODS}

The Eexperiment was conducted in the Laboratory of Feed Technology, Department of Animal Science, Faculty of Animal and Agriculture Sciences, Diponegoro University. Experiment was conducted using a completely randomized design with 6 treatments and 5 replications of each. Hatchery wastes that consisting of egg shells, rotten eggs, un-hatched eggs, and culled DOC were mixed and blended with home cooking blender for 5 minutes, then added with cassava waste meals (onggok) as filler by 10\% (W/W in fresh weight) and thoroughly mixed well. After that, zeolite as the treatment was administered into the mixture of hatchery waste and cassava waste meals by $0,1,2,3,4$ and $5 \%$ (W/W), then mixed well. The mixture of hatchery wastes was conditioned at a temperature of $\pm 80^{\circ} \mathrm{C}$ for 5 minutes, and pelletized by extruder to make pellets with a diameter of $5 \mathrm{~mm}$ and length of $30 \mathrm{~mm}$. Then it was dried on warm air flows until the moisture content reaches 10-12\%. The texture, color, odor of pellet product was evaluated by 15 (fifteen) trained panels, the durability measured by Holmen pellet tester. Data of texture, color, odor of pellets were analyzed with descriptive qualitative analysis, whereas durability analyzed by ANOVA to find the effect of the treatment of the physical quality of products hatchery waste pellets.

\section{RESULTS AND DISCUSSION}

The results showed that the pellet form is quite good, flat and smooth of surfaces, slightly rough of texture and uniform of size. As evident in the table 1, there was an increasing trend on decision of the panel that the pellet product was excellent and good and proportionally to the decrease in the number of panels that judge fairly. However, 6.7$13.3 \%$ panels stated that the physical form of pellets poor. The observation to the color of the pellets indicates that the majority panelist classified the color pellets added with zeolite (2-5\%) are excellent and good, with descriptions it is clear and no visible spots found. To the pellets products added with zeolites $0-1 \%$, the panel describes the pellet referred to ugly dull color. 
Table 1.The texture, odor, color and durability of product pellet of hatchery wastes at various levels zeolite additions

\begin{tabular}{|c|c|c|c|c|c|c|c|c|c|}
\hline \multirow{2}{*}{$\begin{array}{l}\text { Level zeolite } \\
(\% \mathrm{~W} / \mathrm{W})\end{array}$} & \multicolumn{3}{|c|}{ Texture } & \multicolumn{3}{|c|}{ Odor } & \multicolumn{2}{|r|}{ Color } & \multirow{2}{*}{ Durability (\%) } \\
\hline & \multicolumn{8}{|c|}{--------- \% panels --------- } & \\
\hline \multirow[t]{4}{*}{$0 \%$} & $* \mathrm{E}$ & $=$ & 6.7 & $\mathrm{E}$ & $=$ & 0.0 & $E$ & 6.7 & $84.92 \pm 0.44^{\mathrm{a}}$ \\
\hline & $\mathrm{G}$ & $=$ & 13.3 & $\mathrm{G}$ & $=$ & 13.3 & $\mathrm{G}$ & 20.0 & \\
\hline & L & $=$ & 53.3 & $\mathrm{~L}$ & $=$ & 53.3 & $\mathrm{~L}$ & $=46.7$ & \\
\hline & $\mathrm{P}$ & $=$ & 26.7 & $\mathrm{P}$ & $=$ & 33.3 & $\mathrm{P}$ & 26.7 & \\
\hline \multirow[t]{4}{*}{$1 \%$} & $\mathrm{E}$ & $=$ & 6.7 & $\mathrm{E}$ & $=$ & 6.7 & $\mathrm{E}$ & 6.7 & $84.66 \pm 0.70^{\mathrm{a}}$ \\
\hline & $\mathrm{G}$ & $=$ & 20.0 & $\mathrm{G}$ & $=$ & 13.3 & G & $=20.0$ & \\
\hline & $\mathrm{L}$ & $=$ & 60.0 & $\mathrm{~L}$ & $=$ & 53.3 & $\mathrm{~L}$ & 53.3 & \\
\hline & $P$ & $=$ & 13.3 & $\mathrm{P}$ & $=$ & 26.7 & $\mathrm{P}$ & $=20.0$ & \\
\hline \multirow[t]{4}{*}{$2 \%$} & $\mathrm{E}$ & $=$ & 13.3 & $\mathrm{E}$ & $=$ & 26.7 & $\mathrm{E}$ & 26.7 & $83.98 \pm 0.59^{\mathrm{a}}$ \\
\hline & G & $=$ & 26.7 & G & $=$ & 46.7 & G & $=40.0$ & \\
\hline & $\mathrm{L}$ & $=$ & 46.7 & $\mathrm{~L}$ & $=$ & 20.0 & $\mathrm{~L}$ & 26.7 & \\
\hline & $\mathrm{P}$ & $=$ & 13.3 & $\mathrm{P}$ & $=$ & 6.7 & $\mathrm{P}$ & 6.7 & \\
\hline \multirow[t]{4}{*}{$3 \%$} & E & $=$ & 33.3 & $\mathrm{E}$ & $=$ & 40.0 & $\mathrm{E}$ & 40.0 & $83.02 \pm 0.87^{\mathrm{a}}$ \\
\hline & G & $=$ & 40.0 & G & $=$ & 33.3 & G & 40.0 & \\
\hline & $\mathrm{L}$ & $=$ & 20.0 & $\mathrm{~L}$ & $=$ & 20.0 & $\mathrm{~L}$ & 13.3 & \\
\hline & $\mathrm{P}$ & $=$ & 6.7 & $\mathrm{P}$ & $=$ & 6.7 & $\mathrm{P}$ & 6.7 & \\
\hline \multirow[t]{4}{*}{$4 \%$} & $\mathrm{E}$ & $=$ & 46.7 & $\mathrm{E}$ & $=$ & 40.0 & $\mathrm{E}$ & 40.0 & $83.89 \pm 1.04^{\mathrm{a}}$ \\
\hline & G & $=$ & 33.3 & G & $=$ & 46.7 & G & 40.0 & \\
\hline & $\mathrm{L}$ & $=$ & 13.3 & $\mathrm{~L}$ & $=$ & 13.3 & $\mathrm{~L}$ & 13.3 & \\
\hline & $\mathrm{P}$ & $=$ & 6.7 & $\mathrm{P}$ & $=$ & 0.0 & $\mathrm{P}$ & 6.7 & \\
\hline \multirow[t]{4}{*}{$5 \%$} & E & $=$ & 46.7 & $\mathrm{E}$ & $=$ & 46.7 & $\mathrm{E}$ & 40.0 & $82.15 \pm 0.79^{a}$ \\
\hline & G & $=$ & 33.3 & G & $=$ & 40.0 & G & 46.7 & \\
\hline & $\mathrm{L}$ & $=$ & 13.3 & $\mathrm{~L}$ & $=$ & 13.3 & $\mathrm{~L}$ & 6.7 & \\
\hline & $\mathrm{P}$ & $=$ & 10.2 & $\mathrm{P}$ & $=$ & 0.0 & $\mathrm{P}$ & 6.7 & \\
\hline
\end{tabular}

*E = excellent: Color-the color is bright, evenly, no dark spot; Odor- odorless;Texture- the surface is smooth, no cracks, straight, size uniform; $\mathrm{G}=$ good: Color-the color bright, uneven, there is a little dark spot; Odor- smells somewhat typical eggs or a little bit fishy; Texture- the surface smooth, no signs of subtle cracks, warping, size of some not-uniform; $\mathrm{L}=$ less: Color- the color less bright, there is a spot; Odor- fishy, rather stench; Texture- the surface somewhat uneven, there are no signs of cracks, warping, size is not uniform; $\mathrm{P}=$ poor: Color- the color brownish, many dark patches; Odor- rotten egg smell is very strong; Texture the surface rough, cracks evident, size is not uniform

Observation to the odor of pellet showed quite good. By the treatment of zeolite, almost all panels described the product was good with decreased fishy and foul smells or just slightly typical eggs smells. The increasing number of respondents pointed out that the product was excellent and good in line with the increase of the zeolite percentage administered. Percentage of broken pellets per observation classified as good (5-10\%). The result of durability measurement showed no significant effect of increasing level of zeolite i.e. $84.92 \pm 0.44 \%, 84.66 \pm 0.70 \%, \quad 93.98 \pm 0.59 \%, 83.02 \pm 0.87 \%, 83.89 \pm 1.04 \%$ and $82.15 \pm 0.79 \%$. The product pellet of hatchery wastes could be classified as the soft pellets. 
However, pellet of hatchery waste with the addition of zeolite showed a little more resistance to the friction and pressure rather than the control.

The particle size affects the texture and protein content pellet, the coarser particle size and the lower the protein content of the material will decrease the texture and pellet hardness (Muramastu et al. 2012; Angulo et al. 1995). In this study, the addition of as much as $10 \%$ cassava meal and feather of chicken could be considered as factors in decreasing the texture rather than the zeolite administration, since cassava meal caused larger particle size than zeolite. Effects of zeolite to the odor pellet products in line with the study that evaluate the characteristics and the role of clay minerals in nutrition and feed earlier. Clay minerals having good ability in releasing microelement and adsorption capacity to play role a bind harmful compounds and then dispose of the body (Tenorio Arvide et al. 2008; Tateo \& Summa 2007), and its able to suppress the bacterial effect (Haydel et al. 2008; Mpuchane et al. 2008), as well as absorb the odor of ammonia, which was obvious in this study. Activities bacterial decomposition could be suppressed, so that the decay process was inhibited, fishy and vanished odors were absorbed well, so that the pellets product was not stink.

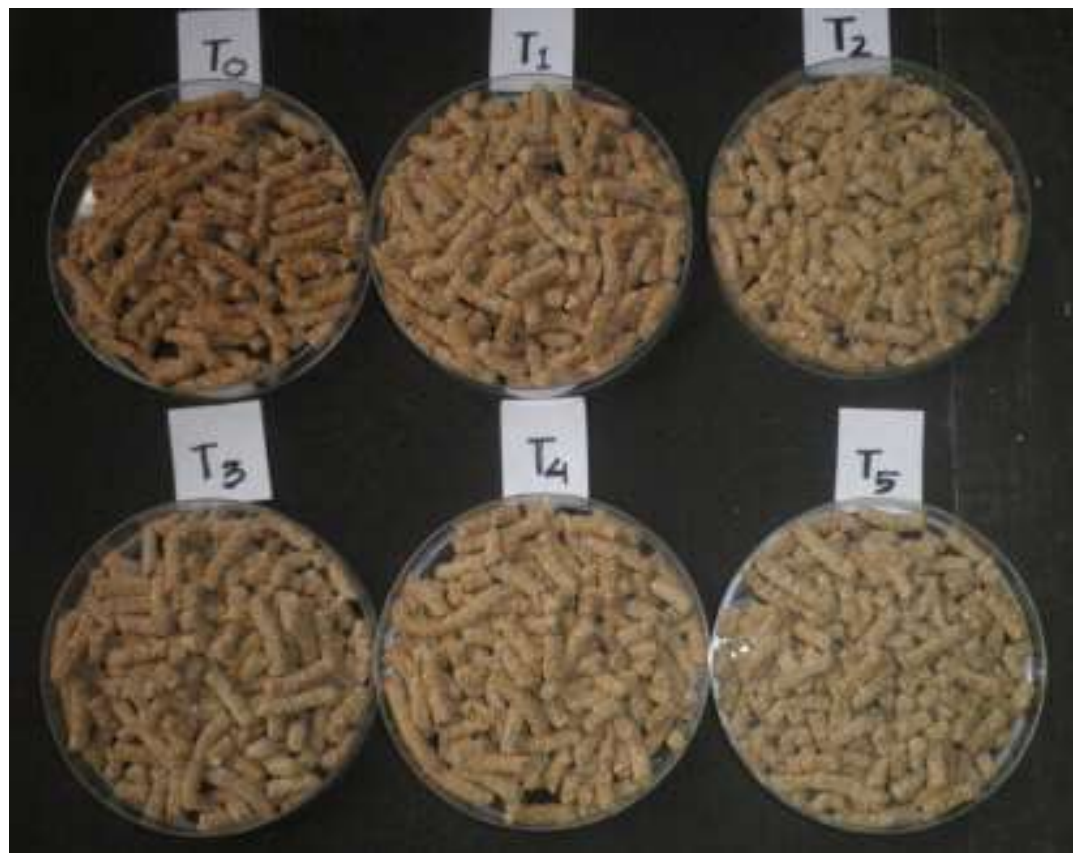

Figure 1.General appearance of pellet product of hatchery wastes at various levels of zeolite additions

Durability is the physical quality indicators of the pellet against to friction or mechanical loadings. It is defined as the ability of pellet to withstand the pressure and destructive loadings. Pellet durability is considered high when the calculated value is above $80 \%$, while if the value is between $70 \%$ and $80 \%$, and low when the value is below 70\% (Colley et al. 2006; Tabil \& Sokhansanj 1996). Durability and hardness of pellets are influenced by conditioning temperatures, nutrition components, length and diameter of the pellet (Thomas \& Van der Poel 1996). The presence of coarse material and conditioning at a lower temperature been reported affect reduction of pellet hardness and its durability (Zimonja \& Shivus 2009; Zafari \& Kianmehr 2012). In this experiment, in spite of the zeolite, nutrient components and raw material used relatively same, no different in the time 
and temperature used in the pellet making, it could be considered as reasons that there was no significant difference on durability of pellets among the treatments.

\section{CONCLUSION}

It is concluded that addition of $4 \%$ of zeolite in hatchery wastes pelletizing process was able to improve physical appearance of the pellet products. Further studies to observe its ability on maintaining physic-organoleptic performances during storage as well as that effect on nutrient availability of the pellet products are needed to obtain a more comprehensive recommendation administering zeolite in order to use hatchery waste as alternative feedstuffs.

\section{REFERENCES}

Aarseth KA, Prestløkken E. 2003. Mechanical Properties of Feed Pellets: Weibull Analysis. Biosyst Eng. 84:349-361. DOI:10.1016/S1537-5110(02)00264-7.

Afzal M, Zahid S. 2004. Effects of addition of a mycotoxin detoxifier in poultry feed containing different levels of aflatoxins on the performance of broilers. Asian Australasian J Anim Sci. 17:990-994.

Al-Nasser AY, Al-Zenki SF, Al-Saffar AE, Abdullah FK, Al-Bahouh E, Mashaly M. 2011. Zeolite as a feed additive to reduce Salmonella and improve production performance in Broilers. Intl $\mathbf{J}$ Poult Sci. 10:448-454.

Angulo E, Brufaub J, Esteve-Garcia E. 1995. Effect of sepiolite on pellet durability in feeds differing in fat and fibre content. Anim Feed Sci Tech. 53:233-241.

Behnke KC. 1996. Feed manufacturing technology: current issues and challenges. Anim Feed Sci Technol. 62:49-57.

Cerrate S, Wang S, Coto C, Yan F, Waldroup PW. 2009. Effect of pellet diameter in broiler starter diets on subsequent performance. J Appl Poult Res. 18:590-597. DOI: 10.3382/japr.2009.00041.

Colley Z, Fasina OO, Bransby D, Lee YY. 2006. Moisture effect on the physical characteristics of switchgrass pellets. T ASAE. 49:1845-1851.

Corey AM, Wamsley KGS, Winowiski TS, Moritz JS. 2014. Effects of calcium lignosulfonate, mixer-added fat,and feed form on feed manufacture and broiler performance. J Appl Poult Res. 23:418-428.

Crampton VO. 1985. The application of nutritional findings to the formulation of practical diets. In: Nutrition and feeding in fish. Cowey CB, Mackie AM, Bell JG, editors. p. 447-464. London (UK): Academic Press.

Cutlip SE, Hott JM, Buchanan NP, Rack AL, Latshaw JD, Moritz JS. 2008. The Effect of SteamConditioning Practices on Pellet Quality and Growing Broiler Nutritional Value. J Appl Poult Res. 17:249-261. DOI 10.3382/japr.2007-0008.

Eng KS, Bechtel R, Hutchinson D. 2003. Adding a potassium, clinoptilolite zeolite to feedlot rations to reduce manure nitrogen losses and its impact on rumen ph, E. coli and performance. In: Proceedings South West Nutrition and Management Conference. 18th Annual, February 2003. Tempe (USA): South West Nutrition Conference.

Fasina OO, Sokhansanj S. 1996. Effect of fines on storage and handling properties of alfalfa pellets. Can Agric Eng. 38:25-29. 
Haydel SE, Remenih CM, Williams LB. 2008. Broad-spectrum in vitro antibacterial activities of clay minerals against antibiotic-susceptible and antibiotic-resistant bacterial pathogens. J Antimicrob Chemother. 61:353-361.

Karamanlis X, Fortomaris P, Arsenos G, Dosis I, Papaioannou D, Batzios C, Kamarianos A. 2008. The Effect of a natural zeolite (clinoptilolite) on the performance of broiler chickens and the quality of their litter. Asian-Aust J Anim Sci. 21:1642-1650.

Leung S, Barrington S, Wan Y, Zhao X, El-Husseini B. 2007. Zeolite (clinoptilolite) as feed additive to reduce manure mineral content. Bioresource Technol. 98:3309-3316. DOI 10.1016/j.biortech.2006.07.010.

Lilburn MS, Barbour GW, Nemasetoni R, Coy C, Werling M, Yersin AG. 1997. Protein quality and calcium availability from extruded and autoclaved turkey hatchery residue. Poult Sci. 76:841-848.

Mallek Z, Fendri I, Khannous L, Hassena AB, Traore AI, Ayadi MA, Gdoura R. 2012. Effect of zeolite (clinoptilolite) as feed additive in Tunisian broiler on the total flora, meat texture and the production of omega 3 polyunsaturated fatty acid. Lipid In Health and Disease. [Internet]. Available at http//www.ncbi.nlm.nih.gov/pmc/articles/PMC3364149/pdf/1476-511X-1135.pdf.

Mažeikiene A, Valentukevičiene M, Rimeika M, Matuzevičius AB, Dauknys R. 2008. Removal of nitrates and ammonium ions from water using natural sorbent zeolite (clinoptilolite). J Environ Eng Land Manag. 16:38-44. DOI 10.3846/1648-6897.2008.16.38-44.

Mehdipour M, Shams Shargh M, Dastar B, Hassani S. 2009. Effects of different levels of hatchery wastes on the performance, carcass and tibia ash and some blood parameters in broiler chicks. Pak J Bio Sci. 12:1272-1276. DOI 10.3923/pjbs.2009.1272.1276.url:http//scialert.net/ abstract/?doi=pjbs.2009.1272.1276.

Miazzo R, Rosa CAR, De Queiroz Carvalho EC, Magnoli C, Chiacchiera SM, Palacio G, Saenz M, Kikot A, Basaldella E, Dalcero A. 2000. Efficacy of Synthetic Zeolite to Reduce the Toxicity of Aflatoxin in Broiler Chicks. Poult Sci. 79:1-6.

Mpuchane SF, Ekosse GIE, Gashe BA, Morobe I, Coetzee SH. 2008. Mineralogy of Southern Africa medicinal and cosmetic clays and their effects on the growth of selected test microorganisms. Fresen Environ Bull. 17:547-557.

Muramatsu K, Maiorka A, Vaccari ICM, Reis RN, Dahlke F, Pinto AA, Orlando UAD, Bueno M, Imagawa M. 2013. Impact of particle size, thermal processing, fat inclusion and moisture addition on pellet quality and protein solubility of broiler feeds. J Agric Sci Tech. 3:10171028.

Pappas AC, Zoidi E, Theophilou N, Zervas G, Fegeros K. 2010. Effects of palygorskite on broiler performance, feed technological characteristics andlitter quality. J Appl Clay Sci. 49:276-280. DOI 10.1016/j.clay.2010.06.003.

Pasha TN, Farooq MU, Khattak FM, Jabbar MA, Khan AD. 2007. Effectiveness of sodium bentonite and two commercial products as aflatoxin absorbents in diets for broiler chickens. Anim Feed Sci Technol. 132:103-110. DOI 10.1016/j.anifeedsci.2006.03.014.

Serrano MP, Frikha M, Corchero J, Mateo GG. 2013. Influence of feed form and source of soybean meal on growth performance, nutrient retention, and digestive organ size of broilers. 2 . Battery study. Poult Sci. 92:693-708.

Shariatmadari F. 2008. The application of zeolite in poultry production. World's Poult Sci J. 64:7684. DOI :10.1017/S0043933907001730.

Shahriar HA, Nazer-Adl, K, Doolgarisharaf J, Monirifar H. 2008. Effects of dietary different levels of hatchery wastes in broiler. J Anim Vet. 7:100-105. 
Tabib Z, Jones FT, Hamilton PB. 1984. Effect of pelleting of poultry feed on the activity of molds and mold inhibitors1. Poult Sci. 63:70-75.

Tabil L, Sokhansanj S. 1996. Process conditions affecting the physical quality of alfalfa pellets. Appl Eng Agric. 12:345-350.

Tateo F, Summa V. 2007. Element mobility in clays for healing use. Appl Clay Sci. 36:64-76.

Tenorio Arvide MG, Mulder I, Barrientos Velazquez AL, Dixon JB. 2008. Smectite clay adsorption of aflatoxin vs. octahedral composition as indicated by FTIR. Clay Clay Miner. 56:571-578.

Thomas M, van der Poel AFB.1996. Physical quality of pelleted animal feed 1. Criteria for pellet quality. Anim Feed Sci Tech. 61:89-112.

Trckova M, Matlova L, Dvorska L, Pavlik I. 2004. Kaolin, bentonite, and zeolites as feed supplements for animals: health advantages and risks. Vet Med Czech. 49:389-399.

Watkins KL, Shouthern LL. 1993. Effect of dietary sodium zeolite a on zinc utilization by chicks1. Poult Sci. 72:296-305. DOI 10.3382/ps.0720296.

Zafari A, Kianmehr MH. 2012. Effect of temperature, pressure and moisture content on durability of cattle manure pellet in open-end die method. J Agric Sci. 4:203-208.

Zimonja O, Shiivus B. 2009. Effect of processing of wheat or oats starch on physical pellet quality and nutritional value for broilers. Anim Feed Sci Tech. 149:287-297. 